\title{
Depression of natural killer cell activity by syphilitic serum and immune complexes
}

\author{
JØRGEN RIKARD JENSEN, ANNELISE SPARRE J $\varnothing$ RGENSEN, AND \\ KRISTIAN THESTRUP-PEDERSEN
}

From the Department of Dermatology and Venereology, University of Aarhus, Marselisborg Hospital, Aarhus, Denmark

SUMMARY Consecutive serum samples were obtained from patients with syphilis before and on three occasions after treatment. The sera contained immunosuppresive factors associated with the immunoglobulin fraction, which could depress the natural killer cell activity of healthy controls. There was no evidence that allogeneic or lymphocytotoxic antibodies played a role in immunosuppression, which could be reproduced with both soluble and insoluble antigen-IgG-antibody complexes.

\section{Introduction}

Syphilis is a bacterial infection, which is easily cured with penicillin. It is remarkable that syphilis profoundly changes the cell-mediated immune reactions of the host. The clinical importance of these changes may be important, because many patients may be cured spontaneously. ${ }^{1}$

Previous investigations have shown temporary reduction of several cell-mediated immune reactions in syphilis (personal communication). ${ }^{2-5}$ We have recently reported a depression in natural killer (NK) cell activity in the secondary stage of the disease. ${ }^{7}$ This paper extends our NK cell studies and shows that syphilitic sera contain factors which can inactivate the NK cells. In vitro the depression of NK activity can be reproduced by both soluble and insoluble IgG immune complexes.

\section{Patients and methods}

Twelve women and 12 men participated (mean age 29 years, range 16-52 years) in the study; 11 had primary, nine secondary, and four latent syphilis. Serum samples were obtained before treatment and one, 2-4, and 4-6 weeks after treatment. Sera were stored at $-20^{\circ} \mathrm{C}$ for up to one year and heatinactivated at $56^{\circ} \mathrm{C}$ for 60 minutes before use in the assay.

Twenty-four healthy subjects (10 women and 14 men) served as controls (mean age 31 years, range 18-58 years).

Address for reprints: $\mathrm{Dr} \mathbf{J} \mathbf{R}$ Jensen, Department of Dermatology and Venereology, Marselisborg Hospital, DK-8000 Aarhus C, Denmark

Accepted for publication 4 April 1982
ISOLATION OF LYMPHOCYTES

One hundred millilitres of heparinised blood (20 $\mathrm{IU} / \mathrm{ml}$ heparin) and $10 \mathrm{ml}$ serum were obtained from $\mathrm{O}$ the controls. Phagocytic cells were removed by $\mathbb{\Phi}$ adding $0.2 \%$ carbonyl iron to the blood, and $\vec{\oplus}$ lymphocytes were isolated using Ficoll-Hypaque $\stackrel{\infty}{0}$ gradients. After separation the lymphocytes were washed three times in Hanks' balanced salt solution (HBSS) with $2.5 \%$ fetal calf serum (FCS) and resuspended in RPMI 1640 with $2.5 \%$ FCS to a density of $4 \times 10^{6}$ cells $/ \mathrm{ml}$.

NATURAL KILLER (NK) CYTOTOXICITY ASSAY The target cells used were those from human myeloid cell line K-562, clone 6 , mycoplasma-free. The cell line was generously given by $\mathrm{S}$ Bisballe, Institute of Human Genetics, University of Aarhus. K-562 cells $\stackrel{\mathscr{O}}{=}$ were maintained in RPMI 1640 with $2 \cdot 5 \%$ FCS, penicillin $(100 \mathrm{IU} / \mathrm{ml})$, streptomycin $(100 \mu \mathrm{g} / \mathrm{ml})$, and gentamicin $(1.5 \mu \mathrm{g} / \mathrm{ml})$ in a humidified $5 \% \mathrm{CO}_{2}$ 윽 atmosphere at $37^{\circ} \mathrm{C}$. Target cells $\left(2 \times 10^{6}\right.$ cells $)$ were washed once with HBSS and $0.2 \mathrm{ml}$ were labelled 은 with $0.2 \mathrm{ml}(200 \mu \mathrm{Ci})$ of ${ }^{51} \mathrm{Chromium}\left({ }^{51} \mathrm{Cr}\right.$, Radio- $D$ chemical Centre, Amersham, UK) for 60 minutes at $37^{\circ} \mathrm{C}$. Labelled target cells were washed three times $\mathrm{N}$ in cold HBSS with $2.5 \%$ FCS and resuspended in RPMI 1640 with $2 \cdot 5 \%$ FCS to a concentration of $N$ $1 \times 10^{5}$ cells $/ \mathrm{ml}$.

Effector lymphocytes suspended in RPMI 1640 \% were incubated for 60 minutes at $37^{\circ} \mathrm{C}$ with $50 \%$ o heat-inactivated autologous serum or syphilitic

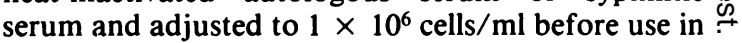
the assay. In parallel, effector cells incubated with sera for 60 minutes were washed three times with $\frac{0}{\Phi}$ HBSS and adjusted to $1 \times 10^{6}$ cells $/ \mathrm{ml}$. Effector $\stackrel{\mathbb{\rho}}{\Phi}$ cells were then mixed with $1 \times 10^{4}$ target cells in $\stackrel{\mathbb{D}}{\varrho}$ 
three effector-to-target cell ratios (E:T: 10:1, 25:1, and 100:1) in a final volume of $1.1 \mathrm{ml}$ in $11 \times 70 \mathrm{~mm}$ polystyrene tubes, centrifuged at $150 \times g$ for five minutes, and incubated for four hours at $37^{\circ} \mathrm{C}$ in a humidified $5 \% \mathrm{CO}_{2}$ atmosphere. After resuspension and recentrifugation, $0.55 \mathrm{ml}$ of the supernates were withdrawn and the release of ${ }^{51} \mathrm{Cr}$ was determined in a gammacounter (LKB, Ultrogammacounter). Tests were performed in triplicate. Spontaneous release (SR) was determined from target cells without effector cells and the maximal release (MR) of ${ }^{51} \mathrm{Cr}$ was determined from target cells in medium after hypotonic lysis. SR never exceeded $20 \%$ of MR. The following formula was used to calculate the percentage of specific lysis:

$$
\frac{\text { cpm Exp-cpm SR }}{\text { cpm MR-cpm SR }} \times 100 \%
$$

where cpm Exp refers to ${ }^{51} \mathrm{Cr}$ release from admixtures with effector cells.

Effector titration graphs were drawn for each experiment with specific lysis as a function of $\log$ $E: T$ ratio. The number of effector cells required to give $50 \%$ specific lysis was determined from the titration curves. The results were expressed as lytic units referring to 1.0 lytic unit as $50 \%$ lysis with $10^{6}$ effector cells. The lytic units of untreated control lymphocytes served as the reference value and the results from serum additions and incubations were finally expressed as the percentage of the reference value.

REMOVAL OF SERUM IMMUNOGLOBULINS Immunoglobulins were precipitated by mixing and incubating the serum with ammonium sulphate $25 \%$ (w/v) overnight at room temperature. After ultracentrifugation at $4000 \times g$ for 30 minutes the supernate was dialysed against $\mathrm{HBSS}$ for 24 hours at $4^{\circ} \mathrm{C}$, filtered $(0 \cdot 22 \mu$ pore size), and used immediately in natural killer assays.

\section{IMMUNE COMPLEXES}

Soluble immune complexes were prepared in vitro from human albumin (Behringwerke) and rabbit anti-albumin-IgG-antibody (Dako) (Ag-Ab). Optimal precipitation was obtained when $600 \mu \mathrm{g}$ of antigen was mixed with $1 \mathrm{ml}$ of antibody. Solutions of immune complexes with antibody excess and antigen excess were made by incubating the mixtures for 30 minutes at $37^{\circ} \mathrm{C}$. The complexes were stored at $-20^{\circ} \mathrm{C}$. Control complexes were suspensions of antigen in HBSS (Ag).

Insoluble immune complexes were prepared from ox erythrocytes coated with rabbit anti-ox-IgGantibody $\left(\mathrm{EA}_{\mathrm{IgG}}\right)$ as described. ${ }^{8}$ Control complexes were ox erythrocytes suspended in HBSS (E).

Lymphocytes $\left(3 \times 10^{6}\right.$ cells $\left./ \mathrm{ml}\right)$ were mixed with immune complexes, centrifuged at $150 \times g$ for five minutes, and incubated at various temperatures for 30 minutes. $\mathrm{EA}_{\mathrm{IgG}}$ complexes were then lysed with $0.83 \%$ Tris $\mathrm{NH}_{4} \mathrm{Cl}$ for 10 minutes. After three washes with HBSS the lymphocytes were resuspended in RPMI 1640 with $2 \cdot 5 \%$ FCS to a density of $1 \times 10^{6}$ cells $/ \mathrm{ml}$ and the NK assay performed.

\section{Results}

Addition of heat-inactivated human autologous serum or heterologous syphilitic serum to test tubes increased the NK activity, whereas a 60-minute incubation period with syphilitic serum resulted in a pronounced depression of the NK activity (table I). The suppression was most pronounced using serum from patients with secondary syphilis. Sera in which

TABLE I Influence of serum on natural killer cell activity agains: $K-562$

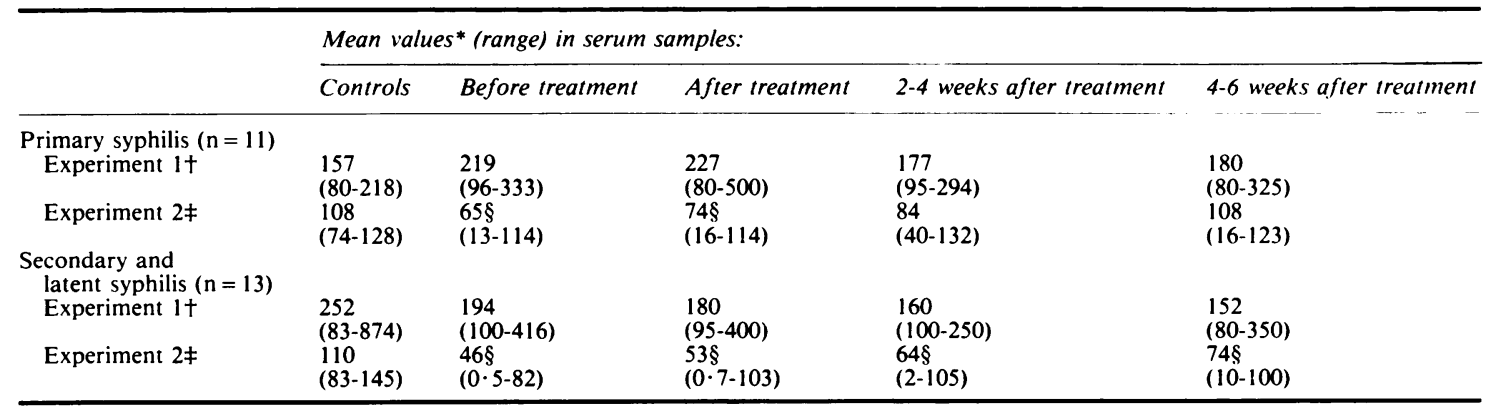

* Mean lytic units expressed as percentage of controls without serum

$+50 \%$ serum was added to lymphocyte-target cell mixtures

$\$ 50 \%$ serum was preincubated with lymphocytes for 60 minutes at $37^{\circ} \mathrm{C}$ followed by three washes with $\mathrm{HBSS}$ before the lymphocytes were mixed with labelled target cells

$\S \mathrm{P}<0 \cdot 01$ (Wilcoxon's test) 
cardiolipin antibodies could not be detected did not depress the NK cell activity.

The increase in the NK cell activity of lymphocytes after the addition of serum and the suppressive factors present in syphilitic sera were associated with the immunoglobulin fractions of the sera (table II). The suppression was not a mere allogeneic phenomenon, because heterologous control serum from five subjects caused no suppression of NK cell activity (data not shown).

The syphilitic sera were examined for lymphocytotoxic antibodies. These cytotoxic antibodies (with and without complement) could not be detected after incubation of sera at $15^{\circ} \mathrm{C}$ or $37^{\circ} \mathrm{C}$ (data not shown).

The depression of the NK cell activity could be reproduced with both soluble and insoluble antigenIgG-antibody complexes (figure).

\section{Discussion}

Because the effective component was found within the immunoglobulin fraction the increase in NK cell activity after the addition of control and syphilitic

TABLE II Influence of immunoglobulin (Ig) on the natural killer cell activity against $K-562$

\begin{tabular}{lll}
\hline & \multicolumn{2}{l}{ Mean values* (range) in: } \\
\cline { 2 - 3 } & $\begin{array}{l}\text { Control } \\
\text { serum }\end{array}$ & $\begin{array}{l}\text { Serum } \\
\text { without Ig }\end{array}$ \\
\hline $\begin{array}{l}\text { Secondary syphilis }(\mathrm{n}=4) \\
\text { Experiment } 1+\end{array}$ & 221 & 97 \\
Experiment $2 \neq$ & $(179-317)$ & $(88-105)$ \\
& 109 & 95 \\
$(83-129)$ & $(80-105)$ \\
\hline
\end{tabular}

* Mean lytic units expressed as percentage of controls without serum $+50 \%$ serum without Ig was added to lymphocyte-target cell mixtures $\neq 50 \%$ serum without Ig was preincubated with lymphocytes for 60 minutes at $37^{\circ} \mathrm{C}$ followed by three washes with HBSS before the lymphocytes were mixed with labelled target cells

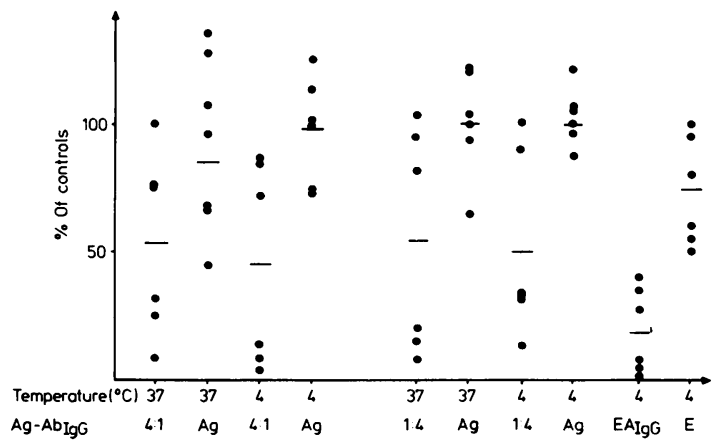

FIGURE Effect of soluble $\left(A g-A b_{l g G}\right)$ and insoluble $\left(E A_{l g G}\right)$ complexes on natural killer cell activity against $K-562$. sera probably reflects an antibody-dependent cellmediated cytotoxicity. Another explanation could be the existence of cytotoxic antibodies towards K-562. After incubation with syphilitic serum, however, there was no increase in spontaneous ${ }^{51} \mathrm{Cr}$ release from labelled target cells.

The depression of NK cell activity after incubation for 60 minutes with syphilitic serum was neither due to allogeneic nor to lymphocytotoxic antibodies. ${ }^{9}$ Possibly, the depression was related to the action of immune complexes in the syphilitic sera. ${ }^{10}$

NK cells are Fc-IgG receptor-bearing cells, ${ }^{11}$ which may be contained within the T-cell population. ${ }^{12} 13$ The NK cell activity can be inhibited in vitro by IgG immune complexes ${ }^{13}$ which may also reduce the concentration in the blood of Ty cells. ${ }^{14}$

This study gives indirect evidence for the role of immune complexes as immunosuppressive factors for NK cells. Immune complexes can depress mitogen reactivity ${ }^{15}$ and their formation may explain the finding of immunosuppressive factors in syphilitic sera. ${ }^{246}$

The biological role of immune complexes in syphilis may be a direct "shut off" signal to B cells, ${ }^{16}$ a blocking of macrophages and their co-operation $\vec{\bullet}$ with lymphocytes, ${ }^{17}$ a stimulation of $\mathrm{Tr}$ cells to release immunosuppressive lymphokines, ${ }^{18}$ or a reduction in NK cell activity or both. ${ }^{7}$

This study was supported by Bloddonorernes Forskningsfond and the Danish Medical Research Council, grant No 12-1740. We are grateful for the laboratory assistance of Ms Anni Jespersen and Mrs Jette Schjфdt and for the secretarial help of Ms Marianne Nielsen.

\section{References}

1. Bruusgaard E. Über das Schicksal der nicht spezifisch behandelten Luetiker. Arch Dermatol Syphilol 1929;157: 309-32.

2. Levene GM, Turk JL, Wright PJM, Grimble AGS. Reduced LTT due to a plasma factor in patients with active syphilis. Lancet 1969; ii: 246-7.

3. Fulford KWM, Brostroff $J$. Leucocyte migration and cell- $\frac{D}{O}$ mediated immunity in syphilis. Br J Vener Dis 1972;48:483-8.

4. From E, Thestrup-Pedersen K, Thulin H. Reactivity of $N$ lymphocytes from patients with syphilis towards Treponema $\Omega$ pallidum antigen in the leucocyte migration and lymphocyte transformation tests. Br J Vener Dis 1976;52:224-9.

5. Wicher $\mathrm{V}$, Wicher $\mathrm{K}$. In-vitro cell response to Treponema $\mathrm{N}$ pallidum-infected rabbits. II Inhibition of lymphocyte $\omega$ response to phytohaemagglutinin by serum of $T$ palliduminfected rabbits. Clin Exp Immunol 1977; 29:487-95.

7. Jensen JR, Thestrup-Pedersen K, From E. Natural killer cell activity in syphilis. Arch Dermatol Res 1982;272: 163-5.

8. Jensen JR. A micromethod for the detection of $T_{G}$ and $T_{M} \mathscr{O}$ cells. Technical aspects for the enumeration of human T-cell subpopulations. Int Arch Allergy Appl Immunol 1982: in press.

9. de Jong NHL, Koehorst JAM, van der Sluis JJ, Boer AM. Autolymphocytotoxins in syphilis. Br J Vener Dis 1980;56: 297-301. 


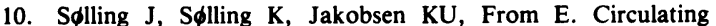
immune complexes in syphilis. Acta Dermatovenereol 1978; 58:263-7.

11. Jondal M, Pross HF. Surface markers on human B and T lymphocytes. VI Cytotoxicity against cell lines as functional markers for lymphocyte subpopulations. Int J Cancer 1975; 15:596-610.

12. Kay HD, Bonnard GD, West WH, Herberman RB. A functional comparison of human Fc-receptor-bearing lymphocytes active in natural cytotoxicity and antibody-dependent cellular cytotoxicity. J Immunol 1977; 118:2058-66.

13. West WH, Cannon GB, Kay HD, Bonnard GD, Herberman RB. Natural cytotoxic reactivity of human lymphocytes against a myeloid cell line: Characterization of effector cells. $J$ Immunol 1977; 118: 355-61.

14. Jensen JR, From E. Alterations in $T$ lymphocytes and T-lymphocyte subpopulations in patients with syphilis. $\mathrm{Br} J$ Vener Dis 1982; 58: 18-22.
15. Ryan JL, Arbeit RD, Dickler HB, Henkart PA. Inhibition of lymphocyte mitogenesis by immobilized antigen-antibody complexes. J Exp Med 1975; 142:814-26.

16. Williams jun RC. Cellular effects of immobilized immune complexes. In: Immune Complexes in Clinical and Experimental Medicine. Harvard, USA: Harvard University Press, 1980.

17. Rabinovitch M, Manejias RE, Nussenzweig V. Selective phagocytic paralysis induced by immobilized immune complexes. J Exp Med 1975; 142: 827-38.

18. Moretta L, Mingari MC Moretta A, Cooper MD. Human T-lymphocyte subpopulations: Studies of the mechanism by which $T$ cells bearing $F c$ receptors for $I g G$ suppress T-dependent B-cell differentiation induced by PWM. Immunol 1979; 122:984-90. 